\title{
MADCAM1 wt Allele
}

National Cancer Institute

\section{Source}

National Cancer Institute. MADCAM1 wt Allele. NCI Thesaurus. Code C122913.

Human MADCAM1 wild-type allele is located in the vicinity of 19p13.3 and is approximately $16 \mathrm{~kb}$ in length. This allele, which encodes mucosal addressin cell adhesion molecule 1 protein, is involved in lymphocyte trafficking. 